\title{
PENDAMPINGAN TERHADAP PENDIDIK PAUD DALAM RANGKA PENGEMBANGAN LEMBAGA PAUD INKLUSIF DI KECAMATAN CIOMAS BOGOR JAWA BARAT
}

\author{
Winda Gunarti ${ }^{1)}$, Siti Nuraini Purnamawati ${ }^{2)}$ \\ Jurusan PG PAUD, Fakultas Ilmu Pendidikan, Universitas Negeri Jakarta
}

\begin{abstract}
ABSTRAK
Pada saat ini pendidikan inklusif sudah mulai diaplikasikan di Indonesia. Pengaplikasian ini dimulai dari jenjang pendidikan anak usia dini sampai ke jenjang sekolah menengah. Berbagai produk hukum dan deklarasi sudah ada bahkan pelaksanaannya juga sudah dilakukan. Namun belum semua tenaga kependidikan memiliki pengetahuan tentang hal ini, untuk itu diperlukan pemberdayaan terhadap mereka.

Jurusan PG PAUD FIP UNJ terpanggil untuk melakukan pendampingan terhadap pendidik PAUD di Kecamatan Ciomas Kotamadya Bogor dalam rangka mengembangkan PAUD Inklusif. Kegiatan ini merupakan kegiatan lanjutan tahun lalu dimana Pendidik PAUD di Kecamatan Ciomas Kotamadya Bogor telah diberikan pembekalan pengetahuan tentang Anak Berkebutuhan Khusus (ABK) yang dilakukan melalui aktivitas seminar dan diskusi atau melalui Forum Group Discussion (FGD).

Kegiatan ini memiliki tujuan untuk memberikan pendampingan pada pendidik PAUD untuk dapat melakukan proses identifikasi dan asesmen terhadap Anak Berkebutuhan Khusus (ABK) sebagai sebuah proses dalam mengembangkan PAUD Inklusif di Wilayah Kecamatan Ciomas Kotamadya Bogor Jawa Barat.
\end{abstract}

Kata kunci : $\quad$ pemberdayaan, inklusif, identifikasi, asesmen, pendampingan

\section{PENDAHULUAN}

\section{A. Analisis Situasi}

Berdasarkan hasil kegiatan Pengabdian Kepada Masyarakat (P2M) yang telah dilakukan pada tahun 2013 yang lalu, ternyata Pemerintah Daerah Kecamatan Ciomas Bogor Jawa Barat dan Himpaudi Kecamatan Ciomas Bogor Jawa Barat, berkeinginan agar ada kegiatan lanjutan dari kelompok kami. Hal ini dibuktikan dengan adanya beberapa anak-anak berkebutuhan khusus (ABK) di daerah tersebut yang menerima pendidikan baik di lembaga Pendidikan Anak Usia Dini (PAUD) maupun di Taman KanakKanak (TK).

Keberadaan anak-anak ini membuat para pedidik di lembaga pendidikan tersebut mengalami hambatan dalam membantu mengoptimalkan potensi anak-anak tersebut.Hal ini dikarenakan mereka belum memiliki pengetahuan bagaimana membelajar-kan mereka dalam lingkungan sekolah atau kelas yang disatukan bersama dengan anak-anak regular (kelas inklusif).

Hal yang penting ketika melakukan pendampingan terhadap pendidik PAUD adalah memberikan pemaha-man tentang Anak dengan Kebutuhan Pendidikan Khusus atau yang lebih dikenal dengan istilah Anak Berkebutuhan Khusus (ABK), Identifikasi dan Asesmen serta Program Pembelajaran Individual. Kegiatan tahun lalu mereka telah mendapatkan pemahaman tentang $\mathrm{ABK}$, sehingga kegiatan tahun ini dilanjutkan dengan pemberian pemahaman tentang Identifikasi dan Asesmen terhadap ABK di lembaga masing-masing.

Untuk itu sebagai bagian dari tanggung jawab kami sebagai akademisi dari Perguruan Tinggi, maka pada tahun ini kami melakukan kegiatan Pengabdian kepada Masyarakat (P2M) berupa workshop tentang Identifikasi dan Asesmen pada anak berkebutuhan khusus sebagai salah satu langkah untuk mengembangkan PAUD Inklusif. 


\section{B. Perumusan Masalah}

Bagaimana pendampingan pada pendidik PAUD di Kecamatan Ciomas Bogor Jawa Barat dalam rangka mengembangkan PAUD Inklusif?

\section{Tujuan Kegiatan}

Kegiatan ini memiliki tujuan untuk memberdayakan pendidik di lembaga PAUD untuk mampu melakukan proses identifikasi dan asesmen perkembangan pada anak berkebutuhan khusus. Kegiatan ini sangat bermanfaat bagi lembaga PAUD yang akan menjadi lembaga PAUD Inklusif.

\section{Manfaat Kegiatan}

Kegiatan ini akan berdampak positif tidak hanya pada para pendidik di lembaga PAUD di lembaga-lembaga PAUD yang akan menjalankan prinsip Education for All, tetapi juga lembaga-lembaga ini telah merespek pada hak ABK dalam memperoleh pendidikan bersama dengan anak lainnya.

Dampak positif lain adalah bagi orangtua yang memiliki ABK tidak akan mengalami kesulitan ketika harus menyekolahkan anak-anak mereka karena beberapa faktor seperti tidak tersedianya Sekolah Luar Biasa di daerahnya, karena mereka dapat memasukkan anak mereka di lembaga PAUD Inklusif. Bagi orangtua yang tidak memiliki ABK mereka akan mengembangkan sikap tepa saliro terhadap orangtua yang memiliki ABK.

Bagi anak-anak yang bukan ABK hal ini akan menjadi pengembangan sikap dan emosional sehingga kelak mereka menjadi anak-anak yang memiliki sikap menghargai dan kerjasama antar mereka. Sebaliknya demikian pula dengan ABK, mereka akan memiliki sikap kemandirian dengan mencontoh anak-anak lain sesuai dengan kemampuan mereka.

\section{TINJAUAN PUSTAKA}

\section{A. Pengembangan Sumber Daya Manusia}

Dalam era globalisasi dimana semua negara akan berlomba bersaing maka bangsa Indonesia tidak dapat menghindar dari persaingan tersebut. Salah satu kekurangan dari bangsa Indonesia adalah masih banyaknya Sumber Daya Manusia (SDM) yang masih memiliki keterampilan yang terbatas.Hal ini yang membuat pemerintahan yang baru mencanangkan ekonomi kreatif untuk memacu pertumbuhan dan perkembangan negara kita.

Untuk membantu perkem-bangan $\mathrm{ABK}$ ini maka salah satu SDM yang penting adalah para guru/pendidik Pendidikan Anak Usia Dini (PAUD). Mereka ikut bertanggung jawab dalam kemajuan $\mathrm{ABK}$ di Indonesia.Upaya untuk mengem-bangkan kompetensi para guru/pendidik PAUD telah dilakukan oleh baik oleh pemerintah daerah maupun oleh Perguruan Tinggi.

Namun tidak semua manusia akan berkembang sama meskipun melalui suatu pengubahan yang sama. Hal ini dikarenakan adanya pengaruh dari factor bawaan dan lingkungan dimana orang itu berada.Disamping itu minat dan niat dari tiap individu juga dapat menentukan perubahan dari individu itu sendiri.

Para pendidik PAUD juga akan mengalami pengubahan dari kegiatan yang akan dilakukan. Namun pengubahan yang menuju pengembangannya akan berbeda antara satu dengan yang lain. Banyak factor yang menunjang pengembangan para pendidik PAUD seperti lingkungan kerja, masyarakat sekitar, dan factor penerimaan terhadap $\mathrm{ABK}$ dari para pendidik PAUD itu sendiri.

\section{B. Pembelajaran Bagi Orang Dewasa}

Pembelajaran bagi orang dewasa tidak terlepas dari unsur pendidikan. Dalam UUSPN No 2 Bab 1 Pasal 1.Berdasarkan pasal ini dapat terlihat bahwa mendidik dilakukan sebagai suatu usaha sadar. Ini berarti dalam mendidik seseorang harus mempersiapkan segala sesuatu yang berhubungan dengan apa yang akan diberikannya.

Kalau ditilik ada perbedaan dalam pembelajaran antara anak-anak dan orang dewasa.Dalam pembelajaran orang dewasa dimana mereka telah siap untuk belajar, para orang dewasa tidak lagi harus dipaksa. Orang dewasa mempunyai kecenderungan memiliki 
orientasi belajar yang berpusat pada pemecahan permasalahan yang dihadapi (Problem Centered Orientation). Hal ini dikarenakan belajar bagi orang dewasa seolah-olah merupakan kebutuhan untuk menghadapi permasalahan yang dihadapi dalam kehidupan keseharian, terutama dalam kaitannya dengan fungsi dan peranan sosial orang dewasa.

\section{Hakikat Pendidikan Anak Usia Dini (PAUD)}

Peraturan Pemerintah Republik Indonesia Nomor 17 tahun 2010, tentang Pengelolaan dan Penyelenggaraan Pendidikan pada Bab I pasal 1 ayat 3 dinyatakan bahwa:

"Program pendidikan anak usia dini jalur pendidikan nonformal sebagaimana dimaksud pada

ayat (1), berfungsi menumbuhkembangkan dan membina seluruh potensi anak sejak lahir sampai dengan usia anak 6 (enam) tahun sehingga terbentuk prilaku dan kemampuan dasar sesuai dengan tahap perkembangannya dalam rangka kesiapan anak memasuki pendidikan lebih lanjut.”. (hal.85.)

Selanjutnya juga dinyatakan bahwa satuan Pendidikan Anak Usia Dini (PAUD) adalah Taman Kanak-Kanak (TK) dan Raudhatul Athfal (RA). Salinan Peraturan Menteri Pendidikan Nasional Republik Indonesia Nomor 58 tahun 2009 tentang Standar Pendidikan Anak Usia Dini pada Bab I Pendahuluan dinyatakan bahwa :

"Penyelenggaraan PAUD jalur pendidikan formal berbentuk Taman KanakKanak (TK)/Raudhatul Atfal (RA) dan bentuk lain yangsederajat, yang menggunakan program untuk anak usia $4-\leq 6$ tahun. Sedangkan penyelenggaraan PAUD jalur pendidikan nonformal berbentuk Taman Penitipan Anak (TPA) dan bentuk lain yang sederajat, yang menggunakan program untuk anak usia0 $-<2$ tahun, $2-<4$ tahun, $4-\leq 6$ tahun dan Program Pengasuhan untuk anak usia0 - $\leq 6$ tahun; Kelompok Bermain (KB) dan bentuk lain yang sederajat, menggunakan program untuk anak usia $2-<4$ tahun dan $4-\leq 6$ tahun".
Sesuai dengan apa yang dinyatakan oleh Kemendiknas melalui Direktorat PAUDNI tentang PAUD terpadu, maka diharapkan di Indonesia akan mulai dikembangkan PAUD Inklusif. Menurut Division for Early Childhood (DEC) and the National Association for the Education of Young Children (NAEYC) PAUD Inklusif adalah:

“...Early childhood inclusion embodies the values, policies, and practices that support the right of every infant and young child and his or her family, regardless of ability, to participate in a broad range of activities and contexts as full members of families, communities, and society. The desired re sults of inclusive experiences for children with and without disabilities and their families include a sense of belonging and membership, positive social relationships and friendships, and development and learning to reach their full potential. The differing features of inclusion that can be used to identify high quality early childhood programs and services are access, participation, and supports".

Batasan ini memberikan pengertian bahwa PAUD Inklusif mendorong semua anak beserta keluarganya melalui nilai-nilai, kebijakan dan praktik agar mereka dapat berpartisipasi dalam keluarga dan masyarakat. Batasan ini memberikan tanda bahwa banyak keuntungan yang diperoleh apabila suatu lembaga PAUD menerima ABK.

\section{Hakikat Identifikasi dan Asesmen}

Menurut ERIC identifikasi adalah “...Recognition of the attributes by which an individual, condition, thing, etc., can be classified". Berdasarkan batasan ini identifikasi adalah menemukenali segala sesuatu berdasarkan kondisi, sesuatu dan sebagainya dari individu.

Pada proses identifikasi maka dilakukanlah screening dengan menggunakan berbagai alat seperti raport perkembangan, laporan dari guru lain dan orang tua. Hal ini sebagai landasan untuk pengem-bangan asesmen.

Menurut American Institute for Research, screening adalah "... conducted to identify or predict students who may be at risk for poor learning outcomes.". Batasan ini menjelaskan bahwa screening atau penyaringan dilakukan untuk mengidentifikasi atau 
meprediksi siswa yang kemungkinan memiliki lemah atau riskan dalam belajar.Jadi dapat dinyatakan bahwa identifikasi dilakukan kepada semua siswa untuk melihat manakah yang bermasalah dalam belajar.

Proses selanjutnya adalah asesmen. Menurut Mercer (1983) asesmen adalah mengukur kemampuan anak sekarang yang meliputi kekuatan dan kelemahannya. Dalam proses asemen digunakan berbagai tes dan non tes. Tes biasanya menggunakan alat-alat yang telah distandarkan seperti tes intelegensi, tes bakat dan minat bahkan secara internasional. Untuk non tes biasanya guru dapat mengembangkan sendiri berdasarkan kurikulum atau standar perkembangan anak. Alat yang digunakan biasanya berupa pedoman observasi baik terstruktur maupun tidak terstruktur seperti catatan anekdot.

Untuk usia dini alat yang digunakan untuk mengidentifikasi biasanya sama dengan yang digunakan untuk anak-anak tingkatan sekolah dasar (SD). Namun untuk pelaksanaannya yang agak berbeda. Untuk anak usia dini identifikasi bisa dilakukan oleh orangtua dan guru selain oleh bidang medis tertentu yang sesuai dengan apa yang dikeluhkan orangtua dan guru serta anak itu sendiri.

Untuk AUD Indonesia standar perkembangan telah dikembangkan oleh pemerintah melalui Peraturan Menteri (Permen) Pendidikan dan Kebudayaan.Permen nomor 58 tahun 2009 berisi tentang standar tingkat pencapaian perkem-bangan.

\section{MATERI DAN METODE}

\section{A. Tempat Pelaksanaan Kegiatan}

Dilakukan di Aula Kantor UPTP XXIX Kecamatan Ciomas Bogor Jawa Barat.

\section{B. Metode Kegiatan}

Kegiatan dilaksanakan dengan cara melakukan kegiatan workshop. Dalam kegiatan workshop peserta terlibat dengan membahas topik tentang pengembangan identifikasi dan asesmen bagi ABK yang ada di lembaga masing-masing.

Untuk tahun mendatang diharapkan kegiatan yang sama akan dilakukan dengan topik pembelajaran bagi ABK di kelas dan dilakukan setiap satu bulan sekali agar pendidik PAUD dapat lebih mantap dalam melakukan pembelajaran bagi ABK di lembaga mereka.

\section{HASIL DAN PEMBAHASAN}

Program pemberdayaan ini dilakukan sejak awal Juni 2013.Langkah awal adalah pencarian data informal melalui wawancara dan diskusi dengan beberapa pendidik PAUD wilayah Bogor Jawa Barat. Berdasarkan hasil wawancara dan diskusi tersebut ternyata terdapat beberapa anak usia dini yang mengalami permasalahan dalam belajar dan beberapa dinyatakan sebagai ABK. Kegiatan ini adalah kegiatan lanjutan tahun 2013.

Pemilihan waktu kegiatan workshop adalah hasil keputusan bersama antara pihak kami, pengawas PAUD tingkat kecamatan Ciomas, Bogor Jawa Barat, dan HIMPAUDI wilayah kecamatan Ciomas, Bogor, Jawa Barat. Hal ini dilakukan agar para pendidik PAUD dapat ikut serta dalam kegiatan ini.

Antusiasme para pendidik PAUD lebih daripada yang di perkirakan, karena mereka menyadari bahwa ABK perlu dilayani sebagai bagian dari hak anak.Banyak pertanyaan yang dilontarkan seputar $\mathrm{ABK}$, dan dari kegiatan pengembangan program pembelajaran bagi ABK masih perlu dilakukan kembali.Hal ini dikarenakan pengembangan program untuk $\mathrm{ABK}$ adalah hal yang baru bagi mereka.

Selanjutnya pengurus HIMPAUDI meminta tim untuk melaksanakan kegiatan lanjutan agar pengem-bangan PAUD INKLUSIF dapat terbina dengan baik. Jika memungkinkan dapat dijadikan pilot project bagi UNJ.

Hasil kegiatan di lapangan juga

menyatakan bahwa pendampingan untuk pengembangan PAUD INKLUSIF sangat perlu dan harus dimotivasi. Hal ini tekait juga dengan adanya buku Pedoman Penyelenggaraan Pendidikan Anak Usia Dini Terpadu yang dikeluarkan pada tahun 2012 oleh Direktorat PAUDNI. Dalam buku ini jelas tertulis "Setiap Satuan PAUD wajib berupaya menampung anak-anak berkebutuhan khusus sebatas kapasitas yang dimiliki dengan tetap menjamin hak-hak anak yang bersangkutan untuk bergaul dengan sesama peserta didik secara wajar serta terlindungi dari perlakuan diskriminatif, baik dari peserta didik lain, pendidik, maupun orang dewasa lainnya"(Kemendikbud, 2012 : h.11). Hal inilah yang harusnya menjadi pemacu semua lembaga PAUD di Kecamatan Ciomas Bogor Jawa Barat untuk mengembangkan dan 
menjadikan lembaga mereka menjadi PAUD Inklusif. Sehingga ABK di daerah Bogor akan dapat berkembang optimal sesuai dengan kondisi dan kebutuhan mereka.

\section{KESIMPULAN}

Hasil kegiatan ini berdampak sangat positif pada semua pihak. Informasi tentang identifikas dan asesmen perlu disosialisasikan secara menerus sehingga pengembangan PAUD Inklusif akan berjalan sesuai dengan baik.

Metoda yang dilakukan ternyata sangat positif mengingat sebagian besar pendidik PAUD memiliki permasalahan yang hampir sama, sehingga dalam kegiatan terjadi sharing yang baik dan tepat.

\section{DAFTAR PUSTAKA}

[1] Early Childhood Inclusion April 2009, http://www.naeyc.org/files/naeyc/file/posi tions/DEC NAEYC EC updatedKS.pd

[2] ERIC http://eric.ed.gov/?ti=Identification Mercer, D, Cecil (1983) Students with Disability Learning, Charles E Merill Publishing, USA

[3] Peraturan Pemerintah Republik Indonesia Nomor 17 Tahun 2010 Tentang Pendidikan Anak Usia Dini. http://pendidikan.kulonprogokab.go.id/ files/Permen-No-58-TH-2009.pdf

[5] Universal Screening, Centre of response to Intervention at American Institute for Research,

[6] http://www.rti4success.org/essentialcomponents-rti/universal-screening content/uploads/2014/08/PP-17-th-10-ttgpenyelenggaraan-pendidikan.pdf

[7] Peraturan Mentri Pendidikan Nasional Republik Indonesia Nomor 58 Tahun 2009 Tentang Standar Pendidikan Anak http://www.paudni.kemdikbud.go.id/wpcontent/uploads/2012/08/ 